\title{
Jihad.cz: Interpreting Jihad, Sexual Jihad and Demographic Jihad in the Czech Anti-Islamic Milieu
}

\author{
Tadeáš Vala ${ }^{1,2} \mathbb{D}$
}

check for updates

Citation: Vala, Tadeáš. 2021. Jihad.cz: Interpreting Jihad, Sexual Jihad and Demographic Jihad in the Czech Anti-Islamic Milieu. Religions 12: 1086. https://doi.org/10.3390/ rel12121086

Academic Editors: Iselin Frydenlund and Eviane Leidig

Received: 19 September 2021 Accepted: 22 November 2021 Published: 9 December 2021

Publisher's Note: MDPI stays neutral with regard to jurisdictional claims in published maps and institutional affiliations.

Copyright: (C) 2021 by the author. Licensee MDPI, Basel, Switzerland. This article is an open access article distributed under the terms and conditions of the Creative Commons Attribution (CC BY) license (https:// creativecommons.org/licenses/by/ $4.0 /)$.
1 Department of Philosophy and Religious Studies, University of Pardubice, 53210 Pardubice, Czech Republic; tadeas.vala@student.upce.cz or tadeas.vala@uhk.cz

2 Department of Political Science-African Studies, University of Hradec Králové, 50003 Hradec Králové, Czech Republic

\begin{abstract}
In the last 10 years, we have seen an increased frequency of fear and criticism of Islam and Muslims in the Czech media scene. Even though the percentage of Muslims in the Czech Republic is tiny (approx. estimate is $0.2 \%$ ), there are active groups and movements in the country that seek to stop the spread of Islam in the Czech Republic, and the discussion of threats from Muslims routinely permeates political statements. A very common argumentation of Czech anti-Islamic claims uses the presentation of jihad as evidence of the danger that threatens the Western world from Muslims. The most widespread understanding of this phenomenon still presents jihad as armed violence against non-Muslims, which is supposed to be clear evidence of the warlike and violent nature of Islam. However, in the Czech-language milieu in recent years, there have also been descriptions of other forms of so-called "creeping" or "stealth" jihad. The article focused on the analysis of the concepts of "population jihad" or "demographic jihad", violent "sexual jihad", "womb jihad" or "wombfare", and the so-called "great replacement" as presented on websites, radio, and social networks by the authors of the Czech-language anti-Islamic milieu. The present text thus illustrated the use of interpretations of sexual and demographic jihad to rationalize the fear and hatred of Muslims and Islam in the Czech Republic.
\end{abstract}

Keywords: jihad; Islamophobia; Czech Republic; populism; Czech anti-Islam; stereotypes; CSPII

\section{Introduction}

Due to the fact that the Muslim community in the Czech Republic is very small, the vast majority of Czech society has minimal or no personal experience with followers of Islam. This is one of the reasons why most of the Czech society has minimal knowledge of Islam (Kropáček 2018, p. 12). Despite this, or perhaps because of it, there has been an increase in negative attitudes towards Muslims and Islam in the Czech Republic in recent years (Baroš et al. 2015, p. 37). Thanks to the small number of followers of Islam in the Czech Republic, we can characterize the Czech case as "Islamophobia without Muslims" (Ostřanský 2016, p. 16). Because of the reduced opportunity to encounter Muslims in everyday situations, many Czech anti-Islamic cases take place mostly on the internet (Muhič Dizdarevič 2016, p. 121; Ostřanský 2018a, p. 25).

An upsurge of Islamophobic attitudes occurred in the Czech Republic, as elsewhere in the West, after 9/11. In the first years after the terrorist attack on the World Trade Center, the Czech far-right scene had not yet addressed the topic of Islam, but in the first half of the 2000s, the first Czech websites focused on criticism of Islam began to emerge. That is also when the anti-Islamic rhetoric of some Czech politicians and movements slowly began to grow (Mareš 2015, p. 77). Some Czech Islamophobic manifestations were imitations of European trends, such as the Czech version of the so-called "struggles for mosques" in the middle of the 2000s when, for example, in the Czech spa town of Teplice, a petition was created against the planned construction of a mosque to serve spa guests from Muslim 
countries, arguing that Islam is incompatible with Czech cultural values (Vojtíšek 2006), while in other cases they were purely local specifics.

At the same time as Islamophobia became a topic in public debates, the topic also became visible in the cultural scene. In 2013, the far-right-leaning band Ortel released its anti-Islamic album Mešita /Mosque, the eponymous track gaining considerable popularity with listeners and even becoming a sort of unofficial anthem at anti-Islamic protests. Thanks to its popularity, the band received prestigious Czech music awards in 2015 and 2016 (Ostřanský 2018b, p. 36). Another controversial reaction was sparked by Olivia Žižková's 2016 song EVROPO DÝCHEJ/EUROPE BREATHE with its clear anti-immigration theme (Ostřanský 2018b, p. 36). In 2014 and 2015, there was a further increase in Czech antiIslamic speech, which is largely related to Islamic terrorist attacks in Europe-such as the Charlie Hebdo attack in January 2015 (Mareš 2015, p. 78)—as well as the so-called refugee crisis and its media coverage.

It is precisely because of the number of refugees and migrants from the Middle East and Africa who have made their way to Europe that radical Islamophobic resistance to Muslims has grown in the Czech Republic. In the context of the refugee crisis, hate speech against Muslims by some politicians, publicists, and media personalities has increased, as has the general distrust of the Czech public toward Islam (Fiala 2016, p. 97; Štampach 2018, p. 179). "Discussions about Islam and Muslims have become an essential part of everyday life, and it is no exaggeration to say that in a way it is almost a national hobby" (Ostřanský 2016, p. 15). Since 2015, Islamophobic tendencies have become intertwined with the issue of the refugee crisis. Among the general public, the words "Muslims" and "migrants" have become almost synonymous, and the arguments against immigration policy have begun to merge with the arguments against Muslims and vice versa (Muhič Dizdarevič 2016, p. 118; Ostřanský 2018b, p. 70).

According to an analysis of the results of the EUvox European Election Calculator conducted by the Institute of Sociology of the Czech Academy of Sciences from 2014, approximately two-thirds of Czechs considered Islam to be a threat to Czech society, a much higher proportion than in European countries wherein Muslims and non-Muslims actually live side by side (OIC Observatory 2015, p. 20). ${ }^{1}$ Anti-Muslim tendencies reached their peak in the second half of 2015 and early 2016, when far-right parties such Dělnická strana sociální spravedlnosti/Workers' Party of Social Justice (DSSS) and Národní demokracie/National Democracy (ND) held a series of demonstrations with Islamophobic and anti-immigration themes (Štampach 2018, p. 179; Mareš 2015, pp. 78-79; Ministerstvo vnitra České republiky 2015a, p. 5). Despite this wave of anti-immigration protests in 2015 and 2016, cyberspace remains the main environment for Islamophobic discussions and attacks, especially on social media (mostly Facebook), which mostly involve insults, calls to violence, fake news, and manipulation of facts to discredit Islam and Muslims (Muhič Dizdarevič 2016, p. 121; 2020, p. 219). "The current Czech public discourse on Islam is indeed distorted, full of confusion and purposeful bending of the facts, whether unintentionally or on purpose, with generalizations and misinterpretations that are unacceptable in other debates" (Ostřanský 2018b, p. 45).

In 2015, topics related to migration and the refugee crisis became quite dominant in the media in the Czech Republic, and there was a noticeable increase in hate speech on social networks and news servers (Hrdina et al. 2016, p. 5). While 84 hate incidents were recorded in 2014, 141 cases were recorded the following year, and each year the type of violence has also changed (Kalibová et al. 2018, p. 255). It is likely that anti-Islamic and anti-immigration hatred in the Czech Republic has been built upon an already existing xenophobic discourse directed against Roma people, when radicals and politicians who initially criticized the "unadaptable" Roma changed their rhetoric to an anti-Islamic discourse, or continued to speak out against the Roma and, newly, against Muslims (Hrdina et al. 2016, p. 31). Selma Muhič Dizdarevič, who regularly produces a report on Islamophobia in the Czech Republic for the European Islamophobia Report, noted in 2015 that the former focus of hate attacks has shifted from the Roma minority to Muslims and in general immigrants from the Middle 
East and Africa (Muhič Dizdarevič 2016, p. 122). Indeed, the proportion of anti-Islamic attacks increased in 2014 and 2015, but the targets of hate attacks against the Roma minority remained. While in 2014 there were 10 cases of anti-Islamic and 34 cases of anti-Romamotivated attacks, in 2015 the ratio was already 30 to 34 (Kalibová et al. 2018, pp. 257-58). This trend continues, as shown by the Ombudsman's 2020 report, which states that $49 \%$ of the hate speech on the internet dealt with by the courts was motivated against Roma, $23 \%$ against Muslims, and $9 \%$ against refugees. Most of these incidents took place on the internet, mostly on social networks, $83 \%$ of which were Facebook (Výzkum veřejného ochránce práv 2020, pp. 9, 19). The negations against Muslims have not replaced the earlier attacks against Romani people, but rather have begun to exist alongside them or have become intertwined with them.

Since at least the turn of 2014 and 2015, we have witnessed the normalization and mainstreaming of Islamophobic manifestations in Czech society (Muhič Dizdarevič 2020, p. 210; Ostřanský 2018b, p. 36). The hate speech against Muslims and Islam that was originally espoused by predominantly extremist individuals and groups has largely taken hold among a number of politicians, journalists, public figures, and especially social media users (Hrdina et al. 2016, p. 31). In the 2010s, there was a significant shift in the perception of hate speech and hostile proclamations in the Czech milieu, which are still considered socially permissible and legally acceptable in the discussion of Islam (Ostřanský 2018a, p. 31). For example, it is quite common to claim that Islam is not a religion but a totalitarian ideology, and the refugee crisis is interpreted as an orchestrated invasion to defeat the West (Fiala 2016, p. 97). Even because of the prevailing fear of Muslims in the broader Czech public, supported by arguments such as a series of Islamist terrorist attacks, critics of Islam understand their anti-Islamic stance to be completely legitimate and correct, and some of them have no problem labelling themselves Islamophobes or downplaying hatred of Muslims (Ostřanský 2018b, p. 34). Many social media users publishing anti-Islamic content do not perceive that their Islamophobic behavior is in any way socially unacceptable and, as a result, do not hide their activity under anonymous accounts, but spread it under their own names (Muhič Dizdarevič 2020, p. 220). For example, the Czech courts have dealt with a Tweet that said, among other things, " ... those Islamist and Gypsy rats, as well as thieving and treasonous politicians, should be shot even with their families ..." (Výzkum veřejného ochránce práv 2020, p. 30). Another user posted a comment on the social networking site with the text "For me, the only good Muslim is a dead one ... " and subsequently defended himself in court by claiming that his criticism of Muslims was his personal opinion (Výzkum veřejného ochránce práv 2020, pp. 26-27). In the words of Czech Middle East specialist and Arab studies expert Bronislav Ostřanský: "The point is not that Czechs are more xenophobic than other nations, but that people abroad are certainly more aware of the inappropriateness of xenophobic speech in public" (Ostřanský 2016, p. 51).

The fear of the unknown, which Islam still is to a large extent in the Czech Republic, certainly has a great influence on Islamophobia in the Czech milieu. Czech anti-Islamic demagoguery thus works based on repeating stereotypes about, for example, violence perpetrated by Muslims, as members of the Islamic State do, and then generalizing that behavior to all Muslims (Fiala 2016, p. 99). "A common feature of anti-Islamic attitudes is the agitation against Islamization, without being able to say exactly what that would mean in the Czech case" (Štampach 2018, p. 180). It is also very common in Czech society to confuse the terms Islamic radicalism, Islamic fundamentalism, Islamism, and Islam. Instead of discussions with substantive arguments, there is often pure demagoguery that spreads panic and fear of Islam (Ostřanský 2018b, pp. 45, 72). Most Czech public discussions about Islam and Muslims are burdened with emotions, ideological schemes, and lack substance. Moreover, in recent years, self-proclaimed specialists and experts on Islam have begun to appear on social media and in the media space in general, which may bring with it serious and even dangerous tendencies in Czech society, which is already susceptible to anti-Islamic speech and especially hateful attacks against Muslims on the Internet (Hošek 2016, pp. 136-37). These authors present various forms of jihad, which 
are supposed to constitute sophisticated tools for the inconspicuous Islamization of the West, which in their subtlety and effectiveness are supposed to be even more dangerous for Western society than jihad in its military form. So, what forms of sexual jihad are used in the Czech-speaking anti-Muslim or Islamophobic milieu to reinforce or increase social negative views, suspicion, or hatred towards Islam and Muslims? Additionally, do the theories of Bill Warner and his organization, the Center for the Study of Political Islam International (CSPII), have a demonstrable influence on the Czech anti-Islamic scene?

\section{Materials and Methods}

For the research, an analysis of texts and statements of individuals, groups, and movements that criticize Muslims in the Czech-language milieu or warn of the Islamic danger, which is why they are often perceived as Islamophobes by the professional and lay public, was applied.

First, an analysis focused on materials_-official or personal websites, statements on social networks (Facebook, YouTube), TV, or radio interviews-of Czech politicians, activists, and radicals who publicly speak out against Islam and Muslims. The analysis focused on the authors with the greatest reach, such as the FB pages of Tomio Okamura, the official website and FB pages of Okamura's political movement SPD, the website of the initiative We Don't Want Islam in the Czech Republic, as well as the domain Eurabia.cz. The focus was on interpretations of jihad, mostly on interpretations of the so-called demographic, population, and sexual jihad. As this article showed, the trope "love jihad" (defined as a strategy by Muslim men to lure non-Muslim women with the intention of marrying them and converting them to Islam as part of an Islamization project) is not significantly used in the Czech-language anti-Muslim milieu, at least not by the authors with the greatest scope for spreading their own ideas. ${ }^{2}$

In addition, Bill Warner's books (Czech translations of books Sharia Law for NonMuslims, The Life of Mohammed, The Islamic Doctrine of Christians and Jews ... in fact, a small number of claims about jihad are repeated over and over again in most of Warner's books), the CSPII website, and public lectures and interviews by members of the Centre subsequently shared on YouTube were analyzed (lectures with titles such as Politický islám jako hrozba pro svobodnou společnost-Political Islam as a Threat to a Free Society, Politický islám a Evropa-Political Islam and Europe, Život Mohameda a jak nás dnes ovlivňuje-The Life of Muhammad and How It Affects Us Today, as in Bill Warner's books, a small number of claims about jihad in the CSPII lectures are quite repetitive). The author of the article also personally attended a CSPII lecture led by Jan Zmeškal on topic Politický islám jako hrozba pro svobodnou společnost-Political Islam as a Threat to a Liberal Society at Café Evropa in Pardubice town on 14 September 2017. The content analysis in all these texts and lectures focused on descriptions of jihad, its types, and specifically the forms referred to as sexual jihad, demographic jihad, and love jihad.

Subsequently, an analysis focusing on direct references to Warner and the CSPII by Czech anti-Islamic politicians and activists, or their conformity with Warner's terminology and theory, was applied.

\section{3. "We Don't Want Islam in the Czech Republic"}

Already a few years after 9/11, the first specialized anti-Islamic websites began to emerge in the Czech Republic, such as Eurabia.cz, founded in 2005 (Mareš 2015, p. 77). In the example of Eurabia.cz, we can see the argumentation shift. The discussion on Eurabia.cz is usually more professional, and the anti-Islamic criticism seems much more sophisticated than in the case of earlier Czech anti-Islamic statements. Much of the antiIslamic controversy was originally very emotional. Vulgarities often appeared in the discussions, and Muslims were often referred to with terms such as "slimák" or "muslimák" (the latter is a pejorative term, a compound of the Czech equivalent of the word Muslimmuslim, and the Czech word for slug-slimák = "muslimák"). In contrast, the discussion on Eurabia.cz highlights real, controversial topics and causes related to Islam and specific 
Muslims, which makes criticism of Islam by the site's editors more socially acceptable. "In this way, opponents of Islam put themselves in the role of thoughtful and aware citizens who have very well thought through and reasoned their position" (Ostřanský 2016, p. 27; Hála 2006). According to the editors of Eurabia.cz, the purpose of the site is to "truthfully inform about the growing danger posed by the creeping penetration of Islam into Europe" and to "open up the debate to all lines of thought that reflect the danger of radical Islam ..." (Eurabia 2006). While the site tries to appear objective and accessible to a broad spectrum of opinion, its editors intend to "reflect the dangers of Islam". The entire site is predominantly focused on the danger of Islamization that is supposed to threaten Europe. Huntington's theory of the clash of civilizations is often mentioned, although mostly only superficially, and the problems of multicultural coexistence in Western European countries-Britain, France, Belgium, or the Netherlands-are presented as a warning example of the situation that could arise in the Czech Republic (Hála 2006). Adam B. Bartoš, leader of the far-right nationalist party National Democracy, was also a former editor of Eurabia.cz. On the website, Bartoš proposed the "controlled expulsion of Muslims from Europe" (Bartoš 2011a) and also identified "Jewish intellectuals and philosophers" who seek to disintegrate Europe's "Christian homogeneous society through, among other things, the concept of multiculturalism" as the instigators of the Islamization of Europe (Bartoš 2011b). The current active editor of the website is Lukáš Lhot'an, a former convert to Islam and ex-Muslim since 2012, whose book Islám E islamismus v České republice/Islam $\mathcal{E}$ Islamism in the Czech Republic (Lhot'an 2011) often functions as an argumentative manual for Czech critics of Islam (Ostřanský 2018b, p. 91). In the spirit of Eurabia.cz, Lhot'an often "proves on the basis of facts and logic why Islam is a threat to the Czech Republic and Europe" (Lhot'an 2019).

The most popular Czech anti-Islamic server, at least in terms of the number of followers, was certainly the Facebook page of the group Islám v ČR nechceme/We Don't Want Islam in the Czech Republic (IVČRN). The origins of this movement date back to 2009, when it was founded on Facebook as a community of debaters with anti-Islamic orientation. According to the Czech Interior Ministry's report on extremism, the group emerged from the former extremist movement Czech Defence League, which was inspired by the English Defence League, an English anti-immigrant organization (Ministerstvo vnitra České republiky 2015a, p. 5). The popularity of IVČRN's Facebook page has gradually increased, and in 2015 it had a fan or follower base of approximately 160,000 people (Šlerka and Fiala 2018, p. 237), i.e., several times more than the estimated number of Muslim members in the Czech Republic. Martin Konvička, the entomologist and leader of the IVČRN movement at the time, faced criminal prosecution for his online statements about Muslims, such as "Fortunately, there will be concentration camps for Muslims, not unfortunately. They demanded for it themselves", or the threat that Muslims would be minced into meat-and-bone meal (ČT24 2018b). Here, we can see the linking of the Czech anti-Islamic scene, as Konvička has published a collection of texts from his blog as a book entitled Sex, drogy a islám/Sex, drugs, and Islam, by the publishing house of the aforementioned ex-Muslim Lukáš Lhot'an (Ostřanský 2018b, p. 91).

IVCRN's Facebook pages have served to mobilize supporters for anti-Islamic demonstrations and as an open space for expressing intolerance, presenting controversial messages without context, and calling for the punishment of people who openly criticize xenophobia and Islamophobia. The site was used to spread various forms of hate speech against Islam, Muslims, and, since 2014, migrants (Muhič Dizdarevič 2016, p. 124; Hrdina et al. 2016, p. 28). At the time of the refugee crisis, entities such as the IVČRN began to represent direct competition to the Czech traditional right-wing extremists. Their rhetoric, which often bordered on the Criminal Code's section on defamation of a nation, race, ethnic or other group, and their radical political demands were virtually indistinguishable from those of the far right. IVČRN and other Islamophobic entities, however, have often distanced themselves from any association with the far-right scene (Ministerstvo vnitra České republiky 2015b, p. 4) in order to appear as a legitimate, non-extremist alternative that fights for something 
rather than against something-for a free Europe, for human rights that are violated in Islam, etc. Due to the spread of hateful and xenophobic speech, the IVČRN Facebook page was blocked on 11 January 2016, but the anti-Islamic activities of its members did not cease (Šlerka and Fiala 2018, p. 237). The members of this group continue their activities on their website (IVCRN.cz), but it no longer has the following of their former Facebook page.

\subsection{Czech Political Representation}

The growing political potential of issues related to Islam and refugees has been discovered by Czech politicians and public officials, from the municipal level to legislators to the head of state. It is the office of the Czech President that is held by perhaps the most openly anti-Islamic statesman in the entire European Union (Ostřanský 2016, p. 51, 2018a, p. 23). President Miloš Zeman has criticized Islam and Muslims even before his election to the position of supreme constitutional officer, which he has held since 2013. For example, in 2011, he said, "I do not believe there are moderate Muslims and radical Muslims. Just as I don't believe there are only moderate and radical communists. There are only Muslims and communists", and that "the enemy [NATO and the West] is anti-civilisation stretching from North Africa to Indonesia. It is home to two billion people and is financed partly by the sale of oil and partly by the sale of drugs" (iDnes 2011). In the same year, Zeman compared Islam to Nazism and described it as a religion of hatred (Buchert and Hamšík 2011). Zeman has not stopped his anti-Islamic and anti-Muslim statements even after he was elected Czech President (OIC Observatory 2015, p. 50). Zeman's anti-Islamic attitudes are demonstrated by the fact that during the anti-immigration protests mentioned above, on the occasion of the celebration of the national holiday on 17 November 2015, the President stood on the same stage as Martin Konvička and supporters of the far-right movement PEGIDA were also present in the audience (Mareš 2015, p. 79). The President's spokesperson, Jiří Ovčáček, subsequently stated that Miloš Zeman was not informed in advance who he would be sharing the stage with (Muhič Dizdarevič 2016, p. 126).

At the beginning of the so-called migration crisis, far-right groups such as the DSSS or ND, as well as more mainstream parties, whether left-wing, right-wing, liberal, or conservative, were already working with the topic of the "Islamic danger" (Ostřanský 2016, p. 28; Mareš et al. 2015). A very vocal media opponent of Islam is the politician and lawyer Klára Samková, who publicly presents Islam as "a totalitarian, anti-human, anti-civilization, anti-evolutionary ideology of the same nature as Nazism, fascism and communism..." , On 18 May 2016, the Chamber of Deputies hosted a discussion of experts on the topic Should We Fear Islam?, to which ambassadors from Muslim countries were invited, but they left the hall during and because of Klára Samková's speech (Ostřanský 2018b, p. 92; Samková 2016c).

Tomio Okamura, a parliamentarian of Japanese-Czech descent, has undoubtedly been the most successful in the Czech political scene with his anti-immigration and anti-Muslim rhetoric. Okamura first founded the right-wing populist party Úsvit přímé demokracie/Dawn of Direct Democracy in 2013, which won parliamentary representation in the same year. In its early days, the party tended to use protest waves against established politics, and anti-immigration and anti-Islamic elements played only a minor role at first, but from 2014 and 2015 these topics began to dominate (Mareš 2015, p. 214). However, internal disputes within the party led to its split in 2015. Okamura was expelled from the parliamentary club of the Dawn of Direct Democracy and subsequently founded a new movement called Svoboda a př́má demokracie/Freedom \& Direct Democracy (SPD). Reactions to the refugee crisis have led to the creation and development of institutional political structures in the Czech Republic that focus mainly on preventing the "Islamic invasion" of Europe and on closing the Czech borders (Muhič Dizdarevič 2016, p. 122). Thus, since the turn of the mid-2010s, the vision of a political career has motivated many anti-Muslim militants to launch cheap verbal attacks on their chosen "civilization's enemy"-Islam (Kropáček 2018, p. 13). 
In the 2016 regional elections, it turned out that while most of the parties and movements were using topics related to the "Islamic danger" in their political program, they did not attract voters and did not win any representative positions (Ú-NK, BPI, DSSS, ND); Tomio Okamura and his SPD party captured the main electoral potential of this part of the electoral spectrum (Echo24 2016). Okamura's party is focused on giving the impression that the Czech Republic is in acute danger of immigration and Islamization and that it needs to start defending itself immediately, otherwise the Czech Republic will end up like the countries in Western Europe that are affected by Muslim crime, and if the Czechs do not defend themselves, they will end up as second-class citizens in their own country (Muhič Dizdarevič 2020, p. 220). With this approach, the SPD has not deviated in any way from the standards of other anti-Islamic groups that indiscriminately label all Muslims and immigrants as criminals and equate Islam with militant Islamism (Ministerstvo vnitra České republiky 2015b, p. 4). The impact of the dissemination of hate speech against Muslims and refugees by members of the SPD movement began to be more strongly discussed in 2017, when, in June and July, the first two allegedly Islamic terrorist attacks related to Islamic themes occurred in the territory of the Czech Republic.

On 1 June 2017, a train crashed into a tree deliberately cut down across the tracks and messages were found in the vicinity of the accident with the heading "Allah akbar" containing text written in Latin in the Czech language and with grammatical errors. Martin Konvička immediately commented on the incident on his Facebook account in the post "Islamist assassination or provocation" with the words: "Someone deliberately cut down the tree and directed it onto the tracks. The police found messages in Arabic" (Beníšková 2017). A similar act of cutting down a tree on a railway track was repeated on $28 \mathrm{July}$, and in both cases the perpetrator was a 70-year-old pensioner, Jaromír Balda, "whose motivation was an attempt to raise fears among the population about the Muslim migration wave and terrorist attacks" (ČT24 2018a). During his trial, Balda confessed to the crimes and testified that he was afraid of the arrival of the migrants and that he had dreams of "them [the migrants] rolling here by train ... and raping our women" (ČT24 2019). According to the prosecutor, Mr. Balda "wanted by his actions to create fear in society about the migratory wave, especially about Muslims" (ČTK 2019). Balda has been an active supporter of the SPD, has been involved in promoting the movement and participated in a personal meeting with party leader Tomio Okamura (Cikorová 2021). Balda testified in court that his attacks were intended to help his political favorites ahead of the parliamentary elections because Muslim migrants, according to his plan, would be suspected of carrying out the attacks (Hanslík 2019). Balda was released from prison after two years and eight months in December 2020. In his first interview after his release, Balda said that he did not feel like a terrorist, but a patriot, and that by his act he "was thinking of ten million Czech people, their pork schnitzel, their culture", and added "I did what I wanted to do, as I wanted to do [... ] to mobilize all of you [Czechs]" (Cikorová 2021).

Balda also said he will no longer vote for the SPD because he does not want the party to be associated "with that terrorist Balda" and instead is voting and will continue to vote for the party of current Prime Minister Andrej Babiš, the ANO (YES) movement (Cikorová 2021). Babiš himself, however, also has experience with rhetoric focused on Islamic issues and migration, e.g., in June 2021 he began to declare slogans such as "I don't want a Muslim Europe!" (Rambousková 2021) and "We don't want to share our country!" (Gavenda 2021). In addition, in an interview he said, "According to some calculations, the Netherlands will be majority Muslim in 2044 and Sweden in 2065, unfortunately these are just facts [... ] I will never allow something similar to happen in the Czech Republic" (Musil 2021). Tomio Okamura subsequently responded to Babiš's remarks against Muslims and migrants by saying: "There is only one original on this topic, and I am convinced that voters would rather have the original than a copy. When you say migration or Islam, most people think of the SPD's policy, not anyone else's" (Rambousková 2021). Prime Minister Babiš also repeatedly declared the opposition's policy to be a "jihad against the government", a "jihad 
against Babiš", which the opposition parties are waging "even at the cost of endangering the lives of our citizens" (Babiš 2021; Malecký 2021).

\subsection{Center for the Study of Political Islam International}

A recent and largely unique group focusing on the issue of Islam and migration in the CSPII was founded in 2014 with the proclaimed goal of "making everyone understand the dangers of the global political dominance of Islam" (CSPII 2015a). According to information on the Czech version of the Center's website, it is a non-profit educational organization that "is interested only in the ideology of political Islam, not in the religion or its followers. Our organization values rational thinking and discussion of political ideas. The world has a new means of discussing Islam-fact-based argumentation and a well-informed, active community" (CSPII 2015e). The founders of this organization, based in the Czech city of Brno, are the American physicist and mathematician Bill Warner and the Czech entrepreneur Milan Podlipný (Votruba 2017). Warner is presented in his books and on the CSPII website as a respected expert on political Islam who predicted a war between Islam and the US before 9/11 (CSPII 2015b; Warner 2015a, p. 65). However, academics dealing with Islam see Warner only as a self-proclaimed expert, a popularizer of anti-Islamic theses, and criticize his methods (Ehinger 2016). Czech and Slovak academics focused on the study of Islam were also asked for their opinion on Warner. Islamic studies scholars, Arabic studies experts, and religious studies scholars agree that "Bill Warner is an American anti-Islam activist [...] who has never seriously studied anything about Islam or other religions," that "in relation to Islam he operates with data that he just smugly makes up without any real relation to real knowledge", but that "unlike other anti-Islam activists operating in the Czech Republic, he is very serious, distanced, and above all offers so-called empirical data, which is why many people consider him an expert. Which is absurd" (Islamonline.sk 2016).

Warner's texts focus on Islamic topics such as the Qur'an, the Prophet Muhammad, Sharia law, or jihad, but based on his alleged experience with scientific theories, the topics in the books are supposed to be described in a way that the reader can understand (CSPII 2015g). His methodology focuses on "simple statistics, graphs, and categorizations" (CSPII 2015d) and assumes that the particular Islamic texts that Warner and CSPII members call "trilogy", i.e., the Qur'an, the Sunna-here working mainly with al-Bukhārī's collection of hadiths - and the Seerah-Prophetic biography (Warner 2015b, p. 5)—are fixed by Islamic doctrine, and by examining (only) the information contained in them, one can (sufficiently) understand Islam and Muslims (CSPII 2015d). It should also be added that Warner works only with the English translation of the Qur'an, but does not specify which particular English translation, and also with the English translations of the Sunnah and the Seerah.

In the Czech Republic, the CSPII focuses on translating Warner's books into the Czech language and organizing public lectures. Active members presenting Warner's ideas during talks, which are then shared on YouTube or during other interviews, are mainly CPSII members Jan Zmeškal and Radek Hála. The translations of Warner's books and the public talks are intended to make people aware of the CSPII's proclaimed truth about so-called political Islam and the threats it poses to Europe: "If we want to save our cultures from destruction, we must defend them through education in the political doctrine of Islam [...] We educate all walks of life in the political doctrine of Islam through an international network of local teams and chapters based on a volunteer basis" (CSPII 2015a).

The CSPII also focuses on the concept of jihad on its website and states that "it must first be understood that jihad is not a holy war" (CSPII 2015c); however, Bill Warner himself has called jihad a holy war in his books (Warner 2015b, p. 12). An active member of this organization, Jan Zmeškal, commented on this dilemma at the CSPII public lectures: "Sometimes it is said that jihad means holy war, and this is partly true, but it is not completely true" (CSPII 2019). Zmeškal resorts to interpreting jihad as holy war when he quotes Muslim texts, more accurately quotes interpreted translations of Arabic texts, in PowerPoint presentations at his lectures (CSPII 2019). Warner himself describes jihad as "a political act with religious motivation" and "a war against the kafirs ${ }^{3}[\ldots]$ to establish 
Sharia law" (Warner 2015a, pp. 12, 14, 30). The CSPII website states that "the literal meaning of the word jihad is 'struggle' or 'effort'" (CSPII 2015f), and Jan Zmeškal adds that "the word jihad means effort in the way of Allah" (CSPII 2019). The founder and members of the CSPII also deal with interpretations of different forms of jihad, so the topics of sexual or demographic jihad are also represented. Zmeškal speaks of these "creeping", or "more subtle", forms of jihad as being more effective, as they are supposed to have a more lasting effect on society than armed forms, adding that "if we don't want our society to be more Islamic [...] then we should pay attention to this non-violent jihad" (Svobodný vysílač 2018). The Centre describes as "creeping/subtle" forms of jihad those versions of jihad that are intended to turn non-Muslim into Muslim societies in a non-violent way, and specifically named are population jihad - the population outnumbering of non-Muslims by followers of Islam; economic jihad-supporting Muslim foundations and Western NGOs that wittingly or unwittingly assist the Islamization of Europe; media jihad—wherein Islam is to be portrayed only positively in the mainstream media and the crimes of Muslims are to be covered up; and educational jihad - the deliberate misleading of society by Arabists or Islamic studies scholars who "paint Islam in rosy colours" (Svobodný vysílač 2018).

\section{Interpretations of Sexual and Demographic Jihad}

The Czech anti-Islamic or Islamophobic scene mostly works with the understanding of jihad as a war effort against the West or non-Muslims. Jihad by the sword is understood by the majority of anti-Islamic authors as various forms of armed struggle, and they add that the actions of Islamist terrorists, such as the attack on the World Trade Center or the terrorist attacks in Europe (Madrid 2004, London 2005, Paris 2015, or Brussels and Berlin 2016), are fully in line with Islam and its concept of (armed) jihad and fully correspond to the actions of the Prophet Muhammad (Warner 2015a, p. 3; Okamura 2017; Votruba 2017; CSPII 2019, 2020; IVČRN 2015, p. 7).

If we focus on the interpretations of the phenomena referred to as sexual or demographic jihad, we find that these topics are not as central and frequent among the examined groups and individuals in the Czech anti-Islamic milieu as, for example, the discussion of jihad by the sword, but they do occur from time to time. For example, at a public lecture organized by the CSPII in 2019, one of the listeners in the audience remarked that he had heard of "jihad by vagina, or demographic jihad", to which the lecturer, Jan Zmeškal, responded that sometimes the term "jihad by womb" is chosen for this activity, but he did not comment further on the topic in his lecture or in the discussion that followed (CSPII 2019). Zmeškal and his colleague Radek Hála devoted much more attention to this topic in an interview for the internet radio Svobodný vysílač/Liberty Broadcaster ${ }^{4}$ when they discussed "lesser-known, and on the whole more inconspicuous, forms of jihad, which, thanks to their quietness, are all the more dangerous in terms of influencing our social life and the systemic organization of our civilization" (Svobodný vysílač 2018). One of these discreet forms of jihad is supposed to be population jihad. He spoke of the parallels between the Arabian Peninsula, or respectively Medina, of Muhammad's time and contemporary Europe. By granting asylum to the Prophet and other Muslims, the inhabitants of Medina have allowed Islam to subsequently become the dominant religion there, and this is supposed to be a similar scenario to that which threatens contemporary Europe because of its policies. In response to the moderator's question about whether the population jihad means that the indigenous population is being outnumbered by Muslims, Zmeškal responded that this is due to the high birth rate of Muslims and other mechanisms that make "Islam as a political system very good at self-replication" (Svobodný vysílač 2018).

Iraqi ex-Muslim and current Christian living in the Czech Republic, Salman Hasan, who gives interviews about his life experiences in Iraq, said that "Islam uses immigration as a weapon, it is part of jihad. It wants to destroy the local culture, just like it did in the Middle East [...] That's why I warn against this kind of immigration. Especially those who come illegally" (Vacík 2015). Zmeškal also agrees with this statement, evidenced when he said that "this process has led to countries like today's Turkey, which were still, for 
example, completely Christian in the 14th century, being completely Islamic today", and that current data suggest that this process is happening faster in today's Western world "due to the fact that the original population has a lower birth rate [...] as it happens in the more developed civilizations" (Svobodný vysílač 2018). The moderator of Svobodný vysílač asked his guests whether the high birth rate of Muslims in Western civilization is caused by generous social benefits, which was agreed upon by Radek Hála, who added that in Belgium, young people-Muslims-are motivated not to work and receive social benefits. Hála said that $70 \%$ to $80 \%$ of social benefits in Belgium go to the $10 \%$ Muslim population (Svobodný vysílač 2018). Tomio Okamura has also warned of this situation, stating "And now the third phase of Islamization is coming, the so-called jihad. This means ever-increasing Muslim demands, support for NGOs that provide positive publicity for the invaders, the construction of mosques with strange funds from overseas, the import of radical preachers, etc." (Okamura 2016).

Political scientist Alexander Tomský, who ran unsuccessfully for the Chamber of Deputies in 2017, is even more explicit about the theory of the Great Replacement and the involvement of the EU and NGOs in this project. He gave an interview as part of his election campaign that year in which he claimed that European NGOs are seeking to replace the native European population with Muslim refugees from Africa and the Middle East (Štrunc 2017). In another interview, he also claimed that "the Brussels nomenclature and mainstream politicians intend to destroy [European] nations, which is why they support [Muslim] immigration" (Bendová 2017). SPD MP Karla Maříková promoted similar ideas on her Facebook profile in January 2019. The Czech Police asked the Chamber of Deputies to extradite Maříková for criminal prosecution on suspicion of the offence of incitement to hatred and defamation of a nation, race, or ethnic group. The reason for this request, which was not granted, was a text in which Maříková compared Muslims to invasive plant species: "It is forbidden to import non-native species of plants and animals into the European Union. Muslim migrants are also not native to Europe and, like invasive species, they represent an unexpected spread and gradual displacement of Europe's native inhabitants. Therefore, they should also be banned from entering the European Union" (Česká justice 2020).

Czech Islamophobic attitudes are often linked to earlier anti-Roma tendencies, criticism of the EU, and nationalism. All of these tendencies can be observed, for example, in the case of Lukáš Lhot'an (Petřík 2018), who said in an interview in 2018 that the problem of Romani converts to Islam is arising in Prague and northern Bohemia. Lhot'an (2018) added to this idea: "Can you imagine what the propaganda of Islamic superiority over non-Muslims and the justification of their criminality by saying that they are actually waging jihad against non-believers can do to some Romani people? When they steal from the infidels? I also know that there is an effort by some NGOs and multicultural activists to build an alliance between Muslims and the Roma community against whites and against Czech patriotism..." Lhot'an identified the EU and the Czech individuals who collaborate with it as the main instigators of this policy. In the interview, Lhot'an also pointed to examples of rape of women by Muslims, adding: "As soon as the number of immigrants/refugees grows here, not only from Muslim countries, but also from Africa, where they have different customs and perceptions of the role of women in society, then in combination with multicultural propaganda in Czech education and on the part of NGOs, we can expect that attacks on Czech women and white women as such will begin to increase ..." (Petř́k 2018). It is with a combination of these arguments that Tomio Okamura and his SPD are celebrating their success, when in their political programme they promote points such as: "We don't want to be a province of the EU", "We reject the EU's immigration policy and goals... We say NO to Islamization". Another agenda item is an end to the abuse of social benefits by "non-working unadaptable citizens who parasitize on the state", which Okamura often refers to as mostly Romani people (SPD 2021).

Czech anti-Islamic authors also mention violent sexual jihad. The blogger Jitka Přikrylová, who, in her own words, had a video focused on the truth about jihad on YouTube, but "because the truth is unwelcome and unwanted there, YT [YouTube] deleted 
the video", explained that "Jihad by love [...] is becoming more and more popular in Afghanistan, Pakistan, etc., where Muslims kidnap Christian women and in India Buddhist women, rape them and force them to marry. Part of all this is the forced acceptance of Islam" (Přikrylová 2020a). Salman Hasan describes these practices from his personal experience in Iraq under the Islamic State: "I was taught: you have the right to rape any woman who is not Muslim. Sexual jihad is part of Islam. So, I practised it and destroyed the lives of many women" (Ševela 2015). This practice is also described by Tomio Okamura when he claims that "what we are seeing in European cities is sexual jihad" (Polák 2016), reacting to incidents of sexual assaults on women by men of North African and Arab origin in the German cities of Cologne and Hamburg during the 2015 year-end celebrations (Die Welt 2016; Pergande 2016). Prrikrylová also commented on the incident on her blog: "It's such an original and well-established pastime of most Arabs or North Africans, it's called Taharrush (Taharrush Gamea/Tahar Rush/Taharrush jama'i) ${ }^{5}$ a rape game. If nothing else, it's very telling of their mentality and view of non-Muslim Europeans" (Přikrylová 2020b). In an article entitled The Sweet Truth About the Religion of Peace and Love, in which she directly refers to the English version of the CSPII website, Prrikrylová provides an explanation of the reasons for this allegedly common Muslim behavior: "Half of all Muslims are born from a union with close relatives, which impacts their IQ and then their physical health, as well as the health of those who come their way," and that "the massive procreation of children born to parents who are close relatives could easily cause virtually irreversible damage to the Muslim gene pool in Muslim culture, including extensive damage to their intelligence, mental and physical health" (P̌rikrylová 2019).

\section{Conclusions}

Czech anti-Islamic attitudes have been undergoing a certain process of rationalization in recent years. The largely emotive Czech Islamophobia that gradually spread after 9/11 includes expressions of unconscious aversion, irrational fear of the foreign, and intuitive loathing often reinforced by shared hatred on social media. The rationalizing process of emotional Islamophobia consists in additionally seeking and finding rational arguments to confirm the threat, wrongness, depravity, or even perversity of Islam (Ostřanský 2016, p. 26). The question of whether Islam is bad or a threat has smoothly transformed in society to the question of why Islam is bad/a threat. Prior to the so-called refugee crisis, the lack of a deeper understanding of Muslims and their religion was common among Czech anti-Islamic attitudes, which was often compensated by detailed knowledge of particular cases more or less related to Muslims (Ostřanský 2018b, p. 69): terrorist attacks = evidence of Islamic tendency to violence; female circumcision or polygamy = evidence of general male chauvinism of Muslims; repression of Yazidis and Christians by the Islamic State = evidence of Islamic hatred of non-Muslims, etc.

In the autumn of 2015, the Institute of Sociology of the Czech Academy of Sciences conducted a survey entitled "What Czechs Think of Muslims ..." , according to which Czechs perceive Muslims as violent, lazy, fanatical, dirty, and immoral individuals who often break the law (Kř́žek 2018, p. 124). Due to the ubiquity of the topic of Islam and migration, Czech politicians have been trying to take positions on Islam since at least 2015, as Islam (without a real significant presence of Muslims in the country) has become a major issue in the fight for voters (Ostřanský 2018a, p. 24). As a result, many politicians define themselves against Islam only occasionally, usually in connection with specific events, such as election campaigns or partial controversial topics, such as the migration crisis (Ostřanský 2018a, p. 26). Using the example of the controversial topic that Islam has definitely become in the Czech Republic, we can divide the Czech political scene into (a) a number of right-wing extremists, (b) Islamophobic extremist entities that often distance themselves from association with the extreme right-wing scene (Ministerstvo vnitra České republiky 2015a, 2015b, p. 4), (c) politicians who use the issue before elections to damage political competition, as well as (d) political groups that do not consider Muslims and migration to be a serious threat, but if they were to present their views publicly and loudly, 
they would risk losing part of their voter base. The Czech political scene has thus become largely Islamophobic after 2015 (Ostřanský 2016, pp. 51-52).

In the second decade of the 21st century, we can observe the intermingling of nationalist and Islamophobic tendencies and their mainstreaming in the Czech Republic, with the associated scaremongering about Islamic migration and population/demographic jihad, which are presented as a controlled tool against European nations. While in the first years after 9/11 Islamophobic expressions were made primarily by far-right movements (DSSS), which added hate speech against Muslims to their traditional attacks on Romani people and anti-Semitic rhetoric, since the refugee crisis topics related to Islam have resonated in the discussions and programs of parliamentary parties as well. Current political parties, such as Tomio Okamura's SPD, are intertwining nationalist themes, such as the call for a Chexit and the regaining of national sovereignty, which is to be denied to the Czechs by the EU, with themes such as Islamization, since the controlled Islamization of Europe is supposed to be one of the EU's agendas: "The immigration crisis and the Islamization of Europe, these are organized processes aimed at the destruction of nation states and the creation of a European superstate. Immigration is being used as a weapon" (SPD 2016, p. 10). Prime Minister Andrej Babiš also used this theme against the opposition at the beginning of 2021 when he was asked what would happen if his ruling ANO party did not win the next elections to the Chamber of Deputies (October 2021). Babiš explained that the opposition is being led by "green fanatics" from the European Parliament and that if they win, "we will have the migrants they want here. That's the kind of fair migration-that's what we see happening in Western Europe. I have always been against illegal migration and with Viktor Orbán we pushed for the cancellation of quotas [for the distribution of refugees in EU countries]" (Sloupová 2021).

There is a big difference between what is claimed about Islam by experts who study the religion and perhaps have spent some years in Muslim countries and what the average Czech thinks about Islam, what they repeatedly hear in the media, and what is presented to them by various Czech political representatives. Into this situation stepped Bill Warner and his CSPII, in whose person and organization there was a seeming merger of expertise with mainstream views already influenced by the xenophobic attitudes previously represented mainly by the far right. Warner is supposed to be "an expert who has studied the Qur'an and other Muslim source materials", who does not work with "emotions but only with facts", and whose "method" (Warner 2015a, p. 65; CSPII 2015e) proves that it is not irrational to fear Islam and Muslims but, on the contrary, it would be irrational not to prepare precisely for the threats coming from Islam. As a result, his ideas are openly reproduced by Czech anti-Islamic actors, who often present Warner as the only real expert on Islam. The CSPII is often much more sophisticated in its criticism of Islam than many Czech opponents of Islam, providing critics of Islam with hard data to confirm their claims about the undoubted danger that Muslims pose to the Czech Republic, Europe, and Western civilization.

In the book The Islamophobia Industry, Nathan Lean "shows that the recent spike in anti-Muslim sentiment in the United States and Europe is not the result of a naturally evolving climate of skepticism but a product that has been carefully and methodically nurtured over the past decade and is only now in the second decade of the twenty-first century reaching its desired peak" (Lean 2012, p. 13). In the book, Lean frequently mentions the well-known American anti-Muslim author Robert Spencer (Lean 2012, pp. 9-10, 63-64) and his involvement in the process of the "Islamophobia industry", which is "a growing enterprise, one that is knowledgeable about the devastating effects of fear on society and willing to produce and exploit it", that has "managed and continues to attach Islamophobia permanently to the banner of right-wing populism" (Lean 2012, p. 183). Spencer explains in his book, Stealth Jihad, that terrorist attacks are just one form of Muslim initiatives to take over the world for Islam, and that "the West today faces the threat of stealth jihadists", who "are leading a full-scale effort to transform pluralistic societies into Islamic states, and to seep away Western notions of legal equality, freedom of conscience, freedom of speech, and more" (Spencer 2008, pp. 4-7). A very similar view 
is found in the CSPII members interviewed on "Silent, stealth jihad and its types as a danger to our civilization," where Zmeškal and Hála explained that these forms of jihad are far more dangerous than terrorist attacks because of their effectiveness (Svobodný vysílač 2018). Zmeškal also takes up Spencer's criticism of the use of the phrase "radical Islam" (Spencer 2008, p. 4; CSPII 2019) and also Spencer in his description of "stealth jihad", writing that "Islamic groups will continue [ . . ] to pursue their cause in our schools and universities, in the courts, and in the workplace" (Spencer 2008, p. 269) because of efforts to facilitate the Islamization of the West, and Zmeškal and Hála refer to such actions as "educational jihad" (Svobodný vysílač 2018).

CSPII comes with a change of argumentation regarding Islam and jihad; while for most Czech promoters of anti-Islamic theses there is no difference between (Islamic) terrorism and Islam, for Warner's organization this discussion is not important. In its own words, the CSPII studies "political Islam" but defines it only vaguely. While armed jihad, i.e., jihad by the sword, which is understood as any armed struggle against the West and non-Muslims, including terrorist attacks, is important for most Islamophobic discussions, CSPII members come up with the idea that this form of jihad is a fringe issue of Islam and can be openly fought. More dangerous, however, are the less conspicuous "creeping forms of jihad", such as population jihad (Svobodný vysílač 2018), which is seen as "a weapon of planned expansion of the dar al-Islam (house of Islam) and Muslims in Europe as soldiers of this strategy" (Kř́žzek 2018, p. 146). Migration from Muslim countries and the demographic jihad allegedly associated with it, supported by European NGOs and corrupt politicians, is supposed to be a tool to replace the European population (Muhič Dizdarevič 2020, p. 219). Demographic, sexual, or population jihad are therefore terms used in the Czech Republic, since the migration crisis, to justify Islamophobic tendencies or to justify distrust of Muslims who, according to Warner, either wage various forms of jihad against non-believers or are not proper Muslims (Warner 2017, pp. 20-21). In this anti-Islamic conception, in which any overtly or covertly hostile act directed against non-Muslims can be proper jihad (Warner 2015a, p. 32), demographic and sexual jihad are just some of the many viable and justifiable versions of jihad (CSPII 2019).

In his book, Nathan Lean explains that the Islamophobia industry in America is represented by populist right-wing, conservative, evangelical, and pro-Zionist circles that seek to convince their fellow citizens that Muslims are gaining dangerous influence in the West (Lean 2012, pp. 9-11). Other studies show that in both America and Western Europe, negative attitudes towards Muslims and Islam are most strongly and consistently associated with political conservatism and not with liberal currents (Ogan et al. 2014, p. 40). In contrast, the view of Eastern Europe has given rise to the notion that contemporary Islamophobia is "the result of an ancient and persistent anti-Semitism" (Kalmar 2018, p. 14) and that the manifestations of contemporary Islamophobia in Central Eastern Europe are therefore closely intertwined with past and present manifestations of anti-Semitism. The case of the Czech Republic does not support this idea. According to public opinion polls, Jews, unlike Roma or Arabs, who are very often confused with Muslims, are not perceived in a predominantly negative way by the majority of society. ${ }^{6}$ This tendency can also be seen in the election results, wherein far-right parties that combine an anti-Roma and antiMuslim agenda with anti-Semitic statements have not been successful enough. In contrast, the populist right-wing SPD party, which focuses on criticism of migrants/Muslims and "unadaptable citizens" (Roma) but does not primarily focus on issues related to the Jewish minority or the state of Israel, has been successful in the elections. ${ }^{7}$ It is the SPD movement, whose leader, Tomio Okamura, has taken up Warner's ideas and has openly spread them on his social networks.

For Czech (and Slovak) anti-Islamic politicians and activists who directly refer to Warner, his works, and the CSPII, or use his ideas, statistics, and calculations without reference to a source, his sophisticated attitude serves to reinforce their own negative views of Islam and Muslims and to legitimize their own aversion as a legitimate and logical, not radical, position. In the Czech Islamophobic milieu, there is no clear consensus 
on the who, why, and how of what, exactly, is driving the demographic and population jihad. Opinions range from the idea that this is an automatically functioning element of Islamic self-replication, which takes place quite spontaneously on the territory of EU Member States (CSPII), to interpretations that this is a controlled Islamization of Europe by the EU and NGOs (Okamura, Tomský), which fulfils the theory of the so-called Great Replacement. However, there is consensus that this process is underway and there is a growing discussion about how to counter and prevent this occurrence. To this effect, at least programmatically, the CSPII has been conducting its lectures to inform the broadest possible public about the dangers of (political) Islam, Tomio Okamura has been advocating leaving the EU and closing the borders to protect the country, and Mr Balda has derailed two trains to wake up the Czech nation. All these activities are presented by their actors as tools against violent, but mainly against creeping/stealth non-violent forms of jihad. Currently, the theory of sexual, love, or demographic jihad serves in the Czech context to rationalize and justify fear, negation, and even hatred of Muslims.

While jihad by the sword is to be defeated by force, the creeping/stealth jihad, whose forms are supposed to be even more dangerous and insidious, is to be defended against by education and substantive argumentation, which Warner and the CSPII, in their own words, can offer. The success of the influence of Warner and his CSPII can be seen in the Czech and Slovak politicians and anti-Islamic activists who openly or implicitly refer to Warner, his books, and his ideas. For example, the current Slovak Deputy Prime Minister Richard Sulík does not mention Warner and the CSPII in his social media posts, but he repeatedly uses their theses on political Islam (Sulík 2016a) as well as Warner's figures and statistics on the Qur'an (Sulík 2016b). In the Czech Republic, references to ideas of CSPII are much more varied. Martin Konvička directly mentioned Warner when he stated during the aforementioned interview that "as Bill Warner correctly recognized, we [Europeans] are afraid of them [Muslims], we are not assertive enough [towards them]" (Veselovský 2015). There is a label with Warner's name directly on the Konvička-related IVČRN website, which contains several articles with links to Warner's videos, etc. (IVČRN 2016). Klára Samková promotes Warner's book Právo šaría pro nemuslimy/Sharia Law for Non-Muslims on her blog and adds a link to download the book in PDF format (Samková 2016a). Similarly, Jiři Kobza, an SPD parliamentarian, is promoting four of Warner's books on his official website (Kobza 2021). Jan Veleba, a senator and chairman of the SPO party (which ran in coalition with the SPD in the 2016 regional elections), organized a conference in October 2015 entitled Europe, Immigration and Islam to which he invited as speakers, for example, supporters of the U-NK and the SPD chairman himself, and at which Bill Warner also spoke (Kabátová 2015). Although Okamura did not attend Veleba's anti-Islamic conference, in his social media posts he adopts and further spreads Warner's ideas about the "Islamic trilogy" (Okamura 2017) and directly refers to his theories: "Bill Warner even calculated that the Koran contains more anti-Jewish statements than Hitler's Mein Kampf" (Okamura 2019).

Funding: This research was funded by Podpora vědeckých aktivit studentů doktorského a magisterského programu Filosofie, UPa; grant number SGS_2021_016.

Conflicts of Interest: The author declares no conflict of interest.

\section{Notes}

1 This gives a similar impression to the German support for the anti-Islamic movement Pegida, which is much more strongly present in areas of former East Germany, where a small number of Muslims live, compared to areas of former West Germany (Ostřanský 2016, p. 41).

2 For more on the 'love jihad' trope, see (Frydenlund and Leidig Forthcoming).

3 Káfir, pl. Kuffár, is a multi-significant Arabic term for non-Muslims or infidels. The term itself has undergone historical evolution, and various Muslim authors have used it both pejoratively and neutrally. Warner and his followers have adapted the term into the English and Czech plural term "káfiři/kafirs" and interpret it only as a negative designation of non-Muslims by Muslims.

4 The journalistic website Manipulátoři.cz, which focuses on debunking hoaxes, manipulations and fake news, describes Svobodný vysílač as "an internet radio that often spreads various disinformation, conspiracies, and even Russian propaganda" (Cemper 2018). 
5 Taharrush Jamá'í was the 2005 mass sexual assault of women in Egypt by Egyptian security forces, whose members were alleged to have used this act publicly against female protesters during demonstrations in Cairo.

6 A 2017 press release from the Czech Academy of Sciences focusing on the attitudes of the Czech public toward the ethnic groups living in the Czech Republic indicates that while respondents gave the Roma $4 \%$ sympathy to $76 \%$ antipathy and the Arabs $4 \%$ sympathy to $75 \%$ antipathy, Jews were perceived $28 \%$ sympathetically and $17 \%$ unsympathetically (Tuček 2017, pp. 1-2).

7 While the far-right party DSSS received $0.2 \%$ of the vote in the 2017 elections, the SPD got $10.64 \%$ of the vote.

\section{References}

Babiš, Andrej. 2021. Džihád proti vládě, Babišovi. YouTube.com, February 14. Available online: https://www.youtube.com/watch?v= ehdEmMzuuxo (accessed on 19 June 2021).

Baroš, Jiří, Pavel Dufek, and Oskar Varga. 2015. Islám a liberální demokracie: K podmínkám možnosti vzájemného soužití. In Ne islámu! protiislámská politika v České republice. Edited by Miroslav Mareš. Brno: CDK, pp. 17-51.

Bartoš, Adam B. 2011a. Pojd'me se vážně bavit o odsunu muslimů z Evropy. Eurabia.cz, April 11. Available online: https://www. eurabia.cz/Articles/5977-pojdme-se-vazne-bavit-o-odsunu-muslimu-z-evropy.aspx (accessed on 19 June 2021).

Bartoš, Adam B. 2011b. Komu vděčíme za islamizaci? Eurabia.cz, November 17. Available online: https://www.eurabia.cz/Articles/69 22-komu-vdecime-za-islamizaci-.aspx (accessed on 19 June 2021).

Bendová, Jana. 2017. Alexander Tomský: Někdy si připadám jak v komunistickém Československu, když poslouchám ty unionistické lži o pokroku, spolupráci a míru. Týdeník Reflex 18: 24.

Beníšková, Alena. 2017. U Mladé Boleslavi najel vlak do stromu, policie prověřuje úmyslný čin. iDnes.cz, June 1. Available online: https:/ / www.idnes.cz/zpravy/domaci/mlada-boleslav-vlak-nehoda-strom.A170601_133500_domaci_ale (accessed on 23 June 2021).

Buchert, Viliam, and Ivan Hamšík. 2011. Miloš Zeman: Nepřítelem je islám. Reflex.cz, August 4. Available online: https:/ /www.reflex. cz/clanek/zpravy/44753/milos-zeman-nepritelem-je-islam.html (accessed on 21 June 2021).

Cemper, Jan. 2018. Svobodný vysílač aneb vysílač konspiračních teorií všech druhu. Manipulátoři.cz, November 11. Available online: https:// manipulatori.cz/svobodny-vysilac-aneb-vysilac-konspiracnich-teorii-vsech-druhu/ (accessed on 22 July 2021).

Česká justice. 2020. Poslankyně napsala, že migranti jsou invazivní druh, sněmovna ji ke stîhání nevydala. Available online: https: / www. ceska-justice.cz/2020/05/poslankyne-napsala-ze-migranti-jsou-invazivni-druh-snemovna-ke-stihani-nevydala/ (accessed on 10 September 2021).

Cikorová, Kristina. 2021. První český terorista poprvé promluvil. Seznamzprávy.cz, July 7. Available online: https://www. seznamzpravy.cz/clanek/jsem-vlastenec-ne-terorista-jaromir-balda-je-z-vezeni-doma-a-promluvil-169016 (accessed on 20 July 2021).

CSPII. 2015a. [Homepage]. CSPII.org. Available online: https://www.cspii.org/cz/ (accessed on 12 December 2020).

CSPII. 2015b. Author. CSPII.org. Available online: https:/ / www.politicalislam.com/author/ (accessed on 21 July 2021).

CSPII. 2015c. Džihád. CSPII.org. Available online: https://www.cspii.org/cz/vzdelavani/clanky/dzihad/ (accessed on 12 December 2020)

CSPII. 2015d. Metodologie. CSPII.org. Available online: https://www.cspii.org/cz/vzdelavani/metodologie/ (accessed on 2 February 2020).

CSPII. 2015e. O nás. CSPII.org. Available online: https:/ /www.cspii.org/cz/o-nas/ (accessed on 19 July 2021).

CSPII. 2015f. Politický islám v číslech. CSPII.org. Available online: https:/ /www.cspii.org/cz/vzdelavani/clanky/politicky-islam-vcislech/ (accessed on 12 December 2020).

CSPII. 2015g. Vzdělávání. CSPII.org. Available online: https:/ /www.cspii.org/cz/vzdelavani/ (accessed on 2 February 2020).

CSPII. 2019. Politický islám jako hrozba pro svobodnou společnost 24.6.2019. YouTube.com, June 25. Available online: https://www. youtube.com/watch?v=UjtRmInb_eQ\&t=3055s (accessed on 15 February 2021).

CSPII. 2020. Politický islám a terorismus. YouTube.com. Available online: https://www.youtube.com/watch?v=ioHmhJTMgRA (accessed on 5 November 2020).

ČT24. 2018a. Důchodce nechal najet dva vlaky do stromu, podle policie chtěl podnítit nenávist vůči muslimům. Hrozí mu doživotí. ČT24, February 28. Available online: https://ct24.ceskatelevize.cz/domaci/2404243-duchodce-nechal-najet-dva-vlaky-dostromu-podle-policie-chtel-podnitit-nenavist-vuci (accessed on 16 July 2021).

ČT24. 2018b. Stíhání Martina Konvičky za „muslimy v masokostní moučce“ skončilo. Zastavil ho žalobce. ČT24. May 14. Available online: https: / / ct24.ceskatelevize.cz/domaci/2478376-stihani-martina-konvicky-za-masokostni-moucku-skoncilo-zastavilho-statni-zastuoce (accessed on 21 June 2021).

ČT24. 2019. Měl jsem strach ze zmanipulovaných migrantů, vysvětlil senior kácení stromů na koleje. ČT24, January 7. Available online: https: / ct24.ceskatelevize.cz/domaci/2698646-mel-jsem-strach-ze-zmanipulovanych-migrantu-vysvetlil-senior-kacenistromu-na-koleje (accessed on 16 July 2021).

ČTK. 2019. Pro seniora, teroristu' chce státní zástupce 4 roky vězení. Navrhl trest pod sazbou. Lidovky.cz, January 9. Available online: https: / / www.lidovky.cz/domov/senior-terorista-si-zaslouzi-4-roky-vezeni-navrhl-statni-zastupce-slo-by-o-trest-podsazbou.A190109_131923_In_domov_ele (accessed on 20 July 2021).

Die Welt. 2016. Was wir bisher über die Attacken wissen—und was nicht. Welt.de, January 5. Available online: https:/ /www.welt.de/ vermischtes/article150612301/Was-wir-bisher-ueber-die-Attacken-wissen-und-was-nicht.html (accessed on 22 July 2021). 
Echo24. 2016. Okamura se dostal do většiny krajů, ostatní antiislamisté propadli. Echo24, October 8. Available online: https: / / echo24.cz/a/i3QcF/okamura-se-dostal-do-vetsiny-kraju-ostatni-antiislamiste-propadli (accessed on 20 July 2021).

Ehinger, Jessica. 2016. Absolventka Oxfordu: Islám podl'a Billa Warnera. Islamonline.sk, November 24. Available online: https: //www.islamonline.sk/2016/11/absolventka-oxfordu-islam-podla-billa-warnera/ (accessed on 18 February 2021).

Eurabia. 2006. Kdo Jsme. Available online: https://www.eurabia.cz/ShowContent.aspx?id=10 (accessed on 18 June 2021).

Fiala, Jaroslav. 2016. Teorie islámského spiknutí. In Stíny minaretů: Islám a muslimové jako předmět českých veřejných polemik. Edited by Ondřej Berának and Bronislav Ostřanský. Praha: Academia, pp. 97-106.

Frydenlund, Iselin, and Eviane Leidig. Forthcoming. Introduction to "Love Jihad": Sexuality, Reproduction and the Construction of the Predatory Muslim Male. Religions.

Gavenda, Jaroslav. 2021. Nechceme se o nic dělit, křičel Babiš ve Sněmovně. Zahodil tak svůj program. Seznamzpravy.cz, July 3. Available online: https: / / www.seznamzpravy.cz/clanek/nechceme-se-delit-babis-ve-snemovne-zahajil-kampan-utokem-napiraty-156748 (accessed on 20 July 2021).

Hála, Martin. 2006. Strukturální a obsahová analýza serveru Eurabia.cz. Available online: https://migraceonline.cz/cz/e-knihovna/ strukturalni-a-obsahova-analyza-serveru-eurabia-cz (accessed on 15 June 2021).

Hanslík, Hanuš. 2019. Vyděšený harmonikář. Reportéři ČT, April 15. Available online: https:/ / www.ceskatelevize.cz/porady/114274 3803-reporteri-ct/219452801240014/0/65272-vydeseny-harmonikar/ (accessed on 20 July 2021).

Hošek, Pavel. 2016. Ani růžové, ani černé brýle. In Stíny minaretů: Islám a muslimové jako předmět českých veřejných polemik. Edited by Ondřej Berának and Bronislav Ostřanský. Praha: Academia, pp. 136-49.

Hrdina, Matouš, Hana Daňková, and Liudmila Kopecká. 2016. Projevy nenávisti v online prostoru a na sociálních sítích. Available online: https:/ / www.clovekvtisni.cz/media/publications/553/file/1459365027-hate-speech-zaverecnazprava-final-verze.pdf (accessed on 7 June 2021).

iDnes. 2011. Nepřítelem je islám, „připomněl“ světu prezidentský kandidát Zeman. iDnes.cz, June 21. Available online: https://www. idnes.cz/zpravy/domaci/nepritelem-je-islam-pripomnel-svetu-prezidentsky-kandidat-zeman.A110627_175624_domaci_jw (accessed on 23 June 2021).

Islamonline.sk. 2016. Rozumie Bill Warner islámu? Pýtali sme sa islamológov v Českej republike a na Slovensku. Islamonline.sk, November 23. Available online: https:/ / www.islamonline.sk/2016/11/rozumie-bill-warner-islamu-pytali-sme-sa-islamologovv-ceskej-republike-i-na-slovensku/ (accessed on 13 December 2020).

IVČRN. 2015. Islámofilie v kostce: Argumentační manuál o nejčastějších mýtech a lžích o islámu. IVCRN.cz, May 5. Available online: https:/ / www.ivcrn.cz/wp-content/uploads/2014/11/islamofilie-v-kostce.pdf (accessed on 27 March 2020).

IVČRN. 2016. Štítek: Bill Warner. IVCRN.cz. Available online: https://www.ivcrn.cz/tag/bill-warner/ (accessed on 21 July 2021).

Kabátová, Šárka. 2015. Velebova akce islamofobů nakonec proběhla. V tichosti a bez ,průjmu' senátorů. Lidovky.cz, October 29. Available online: https: / www.lidovky.cz/domov/velebova-akce-islamofobu-probehla-v-tichosti-na-kraji-prahy-a-bez-prujmusenatoru.A151029_121011_ln_domov_sk (accessed on 21 July 2021).

Kalibová, Klára, Benjamin Petruželka, and Václav Walach. 2018. Islamofobie a násilí z nenávisti v České republice. In Islamofobie po česku: Český odpor vuiči islámu, jeho východiska, projevy, souvislosti, přesahy i paradoxy. Edited by Bronislav Ostřanský. Prague: Vyšehrad, pp. 249-67.

Kalmar, Ivan. 2018. Islamophobia, Antisemitism, and Populism: Not Only in Eastern Europe. In Understanding and Explaining Islamophobia in Eastern Europe. Special Issue No. 1. Edited by Alexander Yendell. Leipzig: Leipzig University, pp. 13-19.

Kobza, Jiří. 2021. Knihovna Jiřího Kobzy. Jiri-Kobza.cz. Available online: https:/ / www.jiri-kobza.cz/doporucena-literatura/ (accessed on 21 July 2021).

Křižek, Daniel. 2018. Vývoj západních představ o islámu a muslimech: O stereotypech a předsudcích. In Islamofobie po česku: Český odpor vůči islámu, jeho východiska, projevy, souvislosti, přesahy i paradoxy. Edited by Bronislav Ostřanský. Prague: Vyšehrad, pp. 105-54.

Kropáček, Luboš. 2018. Předmluva. In Islamofobie po česku: Český odpor vůči islámu, jeho východiska, projevy, souvislosti, přesahy i paradoxy. Edited by Bronislav Ostřanský. Prague: Vyšehrad, pp. 9-13.

Lean, Nathan. 2012. The Islamophobia Industry: How the Right Manufactures Fear of Muslims. London: Pluto Press, p. 284.

Lhot'an, Lukáš. 2011. Islám E islamismus v České republice. Pstruží: Lukáš Lhot’an, p. 116.

Lhot'an, Lukáš. 2018. Největší džihád je spravedlivé slovo nespravedlivému vládci. Co je džihád a proč ho islám nechápe jen jako násilí. Reflex.cz, August 18. Available online: https:/ / www.reflex.cz/dzihad-islam (accessed on 27 February 2021).

Lhot'an, Lukáš. 2019. Na základě faktů a logiky dokazuje bývalý muslim, proč je islám hrozbou pro Čechy a Evropu. Eurabia.cz, August 21. Available online: https:/ / www.eurabia.cz/Articles/33345-na-zaklade-faktu-a-logiky-dokazuje-byvaly-muslim-procje-islam-hrozbou-pro-cechy-a-evropu.aspx (accessed on 19 June 2021).

Malecký, Robert. 2021. Džihád proti Babišovi. Politický marketing premiéra je za hranicí dobrého vkusu. e15.cz, April 28. Available online: https:/ / www.e15.cz/nazory/robert-malecky-dzihad-proti-babisovi-politicky-marketing-premiera-je-za-hranicidobreho-vkusu-1380018 (accessed on 19 July 2021).

Mareš, Miroslav, ed. 2015. Stručná historie protiislámské politiky na území České republiky. In Ne islámu! protiislámská politika v České republice. Brno: CDK, pp. 75-79.

Mareš, Miroslav, Baroš Jiří, Dufek Pavel, Havlík Vlastimil, Mocht'ak Michal, Varga Oskar, Vejvodová Petra, and Výborný Štěpán. 2015. Ne islámu! protiislámská politika v České republice. Brno: CDK, p. 219. 
Ministerstvo vnitra České republiky. 2015a. Odbor bezpečnostní politiky a prevence kriminality. Extremismus: Souhrnná situační zpráva 4. čtvrtletí roku 2015. Available online: https:/ / www.mvcr.cz/clanek/ctvrtletni-zprava-mv-o-extremismu-703893.aspx (accessed on 16 June 2021).

Ministerstvo vnitra České republiky. 2015b. Odbor bezpečnostní politiky a prevence kriminality. Extremismus: Souhrnná situační zpráva 2. čtvrtletí roku 2015. Available online: http:/ / www.mvcr.cz/soubor/extremismus-souhrnna-situacni-zprava-za-2-ctvrtleti-roku2015.aspx (accessed on 11 June 2021).

Muhič Dizdarevič, Selma. 2016. Islamophobia in Czech Republic: National Report 2015. In European Islamophobia Report 2015. Enes Bayraklı \& Farid Hafez. Istanbul: SETA, pp. 115-30.

Muhič Dizdarevič, Selma. 2020. Islamophobia in Czech Republic: National Report 2019. In European Islamophobia Report 2019. Enes Bayraklı \& Farid Hafez. Istanbul: SETA, pp. 207-50.

Musil, Petr. 2021. Piráti migranty prostě vítají. Neomluvím se jim ani náhodou, vzkazuje Andrej Babiš. CNN.iPrima.cz, June 12. Available online: https:/ / cnn.iprima.cz/pirati-migranty-proste-vitaji-neomluvim-se-jim-ani-nahodou-vzkazuje-andrej-babis27304 (accessed on 25 July 2021).

Ogan, Christine, Lars Willnat, Rosemary Pennington, and Manaf Bashir. 2014. The rise of anti-Muslim prejudice: Media and Islamophobia in Europe and the United States. International Communication Gazette 76: 27-46. [CrossRef]

OIC Observatory. 2015. 8th OIC Observatory Report on Islamophobia. Available online: https://www.oic-oci.org/upload/islamophobia/ 2015/en/reports/8th_Ob_Rep_Islamophobia_Final.pdf (accessed on 13 June 2021).

Okamura, Tomio. 2016. Hidžra, taqíya a džihád. FaceBook.com. July 24. Available online: https:/ /www.facebook.com/tomio.cz/ videos/hid\%C5\%BEra-taq\%C3\%ADya-a-d\%C5\%BEih\%C3\%A1d/1271796969497782/ (accessed on 27 March 2021).

Okamura, Tomio. 2017. Tomio Okamura: Politický islám. YouTube.com, July 4. Available online: https://www.youtube.com/watch?v= H2zrLEyCe3s (accessed on 21 July 2021).

Okamura, Tomio. 2019. Tomio Okamura: Antisemitismus a nenávist proti Židům se v Evropě šiří hlavně kvůli islámu. FaceBook.com. December 27. Available online: https:/ / www.facebook.com/tomio.cz/posts/3024673224210139 (accessed on 21 July 2021).

Ostřanský, Bronislav. 2016. Islám a muslimové českýma očima-dialog, nebo míjení? In Stíny minaretů: Islám a muslimové jako předmět českých veřejných polemik. Edited by Ondřej Berának and Bronislav Ostřanský. Praha: Academia, pp. 14-57.

Ostřanský, Bronislav. 2018a. Islám se vkrádá do našich obýváků: Namísto úvodu. In Islamofobie po česku: Český odpor vưči islámu, jeho východiska, projevy, souvislosti, přesahy i paradoxy. Edited by Bronislav Ostřanský. Prague: Vyšehrad, pp. 15-31.

Ostřanský, Bronislav. 2018b. Islamofobie jako koncept i kolbiště. In Islamofobie po česku: Český odpor vǔči islámu, jeho východiska, projevy, souvislosti, přesahy i paradoxy. Edited by Bronislav Ostřanský. Prague: Vyšehrad, pp. 33-104.

Pergande, Frank. 2016. Übergriffe auf junge Frauen auch in Hamburg. FAZ.net. January 5. Available online: https:/ /www.faz.net/ aktuell/politik/inland/silvesternacht-uebergriffe-auf-junge-frauen-auch-in-hamburg-13997842.html (accessed on 22 July 2021).

Petřík, Lukáš. 2018. Čeští Romové se dávají na islám. Znalec muslimského prostředí přináší znepokojivé informce k útoku na koupališti v Dubí, znásilněné ženě a radikalizaci romské minority... P ParlamentníListy.cz, August 22. Available online: https:/ / www.parlamentnilisty.cz/arena / rozhovory/Cesti-Romove-se-davaji-na-islam-Znalec-muslimskeho-prostrediprinasi-znepokojive-informce-k-utoku-na-koupalisti-v-Dubi-znasilnene-zene-a-radikalizaci-romske-minority-548611 (accessed on 19 September 2021).

Polák, Miloš. 2016. Okamura a stovky lidí na Václaváku: Vlezbruselisté! Evropa zažívá sexuální džihád! ParlamentníListy.cz, February 6. Available online: https:/ / www.parlamentnilisty.cz/arena/monitor/Okamura-a-stovky-lidi-na-Vaclavaku-VlezbruselisteEvropa-zaziva-sexualni-dzihad-420660 (accessed on 22 July 2021).

Přikrylová, Jitka. 2019. Sladká pravda o náboženství míru a lásky. JitkaMoody.cz, January 15. Available online: https:/ /jitkamoody. $\mathrm{com} / \mathrm{p}=596$ (accessed on 21 February 2021).

Přikrylová, Jitka. 2020a. Pravda o džihádu. JitkaMoody.cz, January 11. Available online: https:/ /jitkamoody.com/?p=1232 (accessed on 21 February 2021).

Přikrylová, Jitka. 2020b. Silvestr před 5 léty ukázal barbarství migrantů. JitkaMoody.cz, December 31. Available online: https: / /jitkamoody.com/?p=1952 (accessed on 22 July 2021).

Rambousková, Michaela. 2021. Nechci migranty a cizáky. Babiš rozjel “nahnědlou kampaň”. Seznamzpravy.cz, July 6. Available online: https: / / www.seznamzpravy.cz/clanek/migranti-a-cizaci-babis-rozjel-nahnedlou-kampan-zoufale-hodnoti-politolog156942 (accessed on 20 July 2021).

Samková, Klára. 2016a. Dr. Bill Warner-Právo šaría pro nemuslimy. Available online: https://www.klara-samkova.cz/dr-billwarner-pravo-saria-pro-nemuslimy (accessed on 21 July 2021).

Samková, Klára. 2016b. Klára Samková: Islám je totalitní ideologie. Available online: https:/ /www.youtube.com/watch?v=uSacUqbClc (accessed on 17 July 2021).

Samková, Klára. 2016c. Klára Samková: Máme se bát islámu? (český originál projevu na konferenci 18. 5. 2016). Available online: https:/ / www.klara-samkova.cz/klara-samkova-mame-se-bat-islamu-cesky-original-projevu-na-konferenci-18-5-2016 (accessed on 17 July 2021).

Ševela, Vladimír. 2015. Sexuální džihád je součástí islámu.' Seminář v parlamentu. Echo24.cz, October 20. Available online: https:/ / echo24.cz/a/ipJvJ/sexualni-dzihad-je-soucasti-islamu-seminar-v-parlamentu (accessed on 22 July 2021). 
Šlerka, Josef, and Jakub Fiala. 2018. O sebeprezentaci stránky Islám v ČR nechceme na českém Facebooku. In Islamofobie po česku: Český odpor vưči islámu, jeho východiska, projevy, souvislosti, přesahy i paradoxy. Edited by Bronislav Ostřanský. Prague: Vyšehrad, pp. 235-47.

Sloupová, Miroslava. 2021. Extrémně levicoví Piráti vpustí migranty, řekl Babiš. To říká agent StB, opáčil Bartoš. iDNES.cz, March 12. Available online: https:/ / www.idnes.cz/zpravy/domaci/premier-andrej-babis-volby-pirati-ivan-bartos-stan.A210312_1212 45_domaci_misl (accessed on 10 September 2021).

SPD. 2016. Česká republika—náš bezpečný domov, naše úspěšná budoucnost. SPD.cz. March 8. Available online: https://www.spd. cz/wp-content/uploads/ke_stazeni/program/ceska-republika-nas-bezpecny-domov-nase-uspesna-budoucnost.pdf (accessed on 10 September 2021).

SPD. 2021. Program. SPD.cz. July 10. Available online: https://www.spd.cz/program-vypis/\#7287 (accessed on 10 September 2021). Spencer, Robert. 2008. Stealth Jihad: How Radical Islam is Subverting America without Guns or Bombs. Washington, DC: Regnery Publishing, p. 328.

Štampach, Ivan. 2018. Motivace islamofobních (antiislamistických) postojů zejména v České republice a př́inos religionistiky k jejich analýze. Islamofobie jako koncept i kolbiště. In Islamofobie po česku: Český odpor vuiči islámu, jeho východiska, projevy, souvislosti, přesahy i paradoxy. Edited by Bronislav Ostřanský. Prague: Vyšehrad, pp. 179-200.

Štrunc, Pavel. 2017. Alexander Tomský: Nekorektně o islámu, imigrantech a EU. YouTube.com, September 3. Available online: https:/ / www.youtube.com/watch?v=ULJgOzdRkEI\&t=907s (accessed on 21 July 2021).

Sulík, Richard. 2016a. Islam je len jeden a ten nie je kompatibilný s našou kultúrou. Facebook.com, August 18. Available online: https:/ / cs-cz.facebook.com/RichardSulik/posts/1101516883261372/ (accessed on 21 July 2021).

Sulík, Richard. 2016b. Politický islam je jedna z najnebezpečnejších ideológií. Facebook.com, November 4. Available online: https: //www.facebook.com/RichardSulik/posts/1170174206395639/ (accessed on 21 July 2021).

Svobodný vysílač. 2018. Jan Zmeškal a Radek Hála (Centrum pro studium politického islámu)—Shrnutí nenásilných typů džihádu: Populační, vzdělávací, mediální ekonomický. Jak politický islám latentně působí a jaké využivá prostředky? Svobodnývysílač.cz, November 5. Available online: https://www.svobodny-vysilac.cz/2018-11-05-jan-zmeskal-a-radek-hala-centrum-prostudium-politickeho-islamu-shrnuti-nenasilnych-typu-dzihadu-populacni-vzdelavaci-medialni-ekonomicky-jak-politickyislam-latentne-pusobi-a-jak/ (accessed on 24 February 2021).

Tuček, Milan. 2017. Tisková zpráva: Vztah české veřejnosti k národnostním skupinám žijícím v ČR—březen 2017. Available online: https:/ / crvm.soc.cas.cz/media/com_form2content/documents/c2/a4284/f9/ov170425.pdf (accessed on 20 October 2021).

Vacík, Jakub. 2015. Dřívě muslim, dnes křest’an Salman Hasan: Islám používá imigraci jako zbraň. Deník.cz, October 21. Available online: https:/ / www.denik.cz/z_domova/drive-muslim-dnes-krestan-salman-hasan-uzdravil-me-buh-ne-allah-20151020-u4 mo.html (accessed on 15 January 2021).

Veselovský, Martin. 2015. Konvička: Půjdu do voleb, Sobotka se nám vysmál. DVTV.cz, August 12. Available online: https: / / video.aktualne.cz/dvtv / dvtv-12-8-2015-martin-konvicka-cesko-bez-vody/r \{\}29953baa410b11e5b22d002590604 f2e/r \{\}97dbd78c410a11e5adcb0025900fea04/ (accessed on 21 July 2021).

Vojtíšek, Zdeněk. 2006. Český boj o mešity. Dingir 1: 19-21.

Votruba, Viktor. 2017. Islám je hlavně politické téma, ne náboženské. Mladá Fronta Dnes, December 7. Available online: https: / / cspi-web-media.ams3.cdn.digitaloceanspaces.com/documents/171207_MFD_politicky_islam_Podlipny.pdf (accessed on 9 February 2020).

Výzkum veřejného ochránce práv. 2020. Nenávistné projevy na internetu a rozhodování českých soudů: Sp. zn.:47/2019/DIS/PŽ, Č. j.: KVOP2720/2020. Available online: https://www.ochrance.cz/uploads-import/DISKRIMINACE/Vyzkum/47-2019-DIS-vyzkum_ nenavist.pdf (accessed on 17 June 2021).

Warner, Bill. 2015a. Právo šaría pro nemuslimy. Brno: CSPI International, p. 67.

Warner, Bill. 2015b. Síra-Život Mohameda. Brno: CSPI International, p. 92.

Warner, Bill. 2017. Věcná argumentace: Jak debatovat o islámu. Brno: CSPI International, p. 76. 